Sovan S. Dasgupta

Associate Professor Department of Design \& Automation School of Mechanical Engineering (SMEC) VIT University, Vellore, Tamilnadu,

India

John A. Rajan

Professor

Department of Manufacturing Engineering School of Mechanical Engineering (SMEC) VIT University, Vellore, Tamilnadu,

\title{
Steady-state and Transient Responses of a Flexible Eccentric Spinning Shaft
}

The steady-state and transient dynamics of a flexible spinning shaft with eccentricity driven by a DC motor (i.e., non-ideal energy-source) with external and internal damping is studied in this paper. It is well established that the structural response of a vibratory system to which a non-ideal drive is connected may act as an energy sink under certain conditions such that a part of the energy supplied by the source is spent to vibrate the structure rather than to increase the drive speed. This phenomenon is formally known as the Sommerfeld effect. The Sommerfeld effect characterized by jump phenomena is studied through the steady state amplitude obtained by instantaneous power balance method and further verified through numerical simulation. Transient responses of non-dimensional amplitude and shaft speed wth time evolution through first mode resonance are also given.

Keywords: Sommerfeld Effect, non-ideal source, internal damping, instantaneous power balance, transient response, spinning shaft, .

\section{INTRODUCTION}

An ideal energy source is not influenced by the response of the system. When the excitation is influenced by the response of the system, the corresponding source is said to be non-ideal. A source for which the power supply is limited is said to be non-ideal. On the contrary, an ideal source can draw unlimited amount of power. Arnold Sommerfeld [1] discovered a phenomenon, better known as the Sommerfeld effect, which is characterized by the jumps in the system response at critical values of power input to the source. Several literatures are available on non-ideal systems [1-15]. It is well established that the structural response of the system to which a non-ideal drive is connected may act like energy sink under certain conditions so that a part of the energy supplied by the source is spent to vibrate the structure rather than to increase the drive speed.

The motivation of this research is the first step and fundamental study for response identification of complex rotor systems driven by DC motor. In this paper, a flexible spinning shaft with a constant eccentricity driven by a constant speed DC motor through a dissipative coupling in the presence of internal (material) damping is considered. Multiple jump phenomena occur in such infinite dimensional non-ideal system. Studying the influence of internal damping and external damping parameters on the extent of the Sommerfeld effect zone may aid in designing the controllable damping parameters, so that the high speed rotor-motor system can be operated safely.

\section{MATHEMATICAL MODELING OF THE SHAFT- ROTOR SYSTEM}

The schematic diagram of a slender flexible spinning

Received: June 2017, Accepted: August 2017

Correspondence to: Prof. Sovan S. Dasrupta

VIT University, School of Mechanical Engineering,

Vellore, Tamilnadu, India

E-mail: sovan@vit.ac.in

doi:10.5937/fmet1801133D

(C) Faculty of Mechanical Engineering, Belgrade. All rights reserved shaft with distributed aerial and material damping along with certain constant eccentricity, driven through a DC motor is shown in the Fig. 1. The coupling between the shaft and the motor is assumed to be transversely flexible and light weight. Torsional vibration is not considered in this study, i.e., the whirl speed is not varying along the axis (i.e., $z$-axis) of the spinning shaft and the bearings are assumed to be ideal.

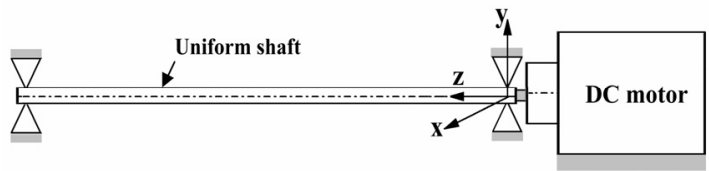

Figure.1. Schematic of DC motor driven flexible shaft

\subsection{Equations of motion of the system}

The equations of motion of the rotor-motor system can be derived by using extended Hamilton's principle [1618] as follows:

$$
\begin{aligned}
& E I \frac{\partial^{4} x}{\partial z^{4}}+\mu_{i} I \frac{\partial^{5} x}{\partial z^{4} \partial t}+\dot{\theta} \mu_{i} I \frac{\partial^{4} y}{\partial z^{4}}+\rho a \frac{\partial^{2} x}{\partial t^{2}}+\mu_{a} E I \frac{\partial x}{\partial t} \\
& -\dot{\theta} I_{r} \frac{\partial}{\partial t}\left(\frac{\partial^{2} y}{\partial z^{2}}\right)=\rho a e \dot{\theta}^{2} \cos (\theta+\varphi)+\rho a e \ddot{\theta} \sin (\theta+\varphi) \\
& E I \frac{\partial^{4} y}{\partial z^{4}}+\mu_{i} I \frac{\partial^{5} y}{\partial z^{4} \partial t}-\dot{\theta} \mu_{i} I \frac{\partial^{4} x}{\partial z^{4}}+\rho a \frac{\partial^{2} y}{\partial t^{2}}+\mu_{a} E I \frac{\partial y}{\partial t} \\
& +\dot{\theta} I_{r} \frac{\partial}{\partial t}\left(\frac{\partial^{2} x}{\partial z^{2}}\right)=\rho a e \dot{\theta}^{2} \sin (\theta+\varphi)-\rho a e \ddot{\theta} \cos (\theta+\varphi) \\
& I_{p} \ddot{\theta}+R_{r} \dot{\theta}=T_{m}-T_{L} .
\end{aligned}
$$

where $\rho$ is the density of the shaft material, $e$ is the constant eccentricity, $\varphi$ is an arbitrary initial orientation of the mass centerline centerline, $a$ is the cross-sectional area of the shaft, $R_{a}$ is the external (direct) damping per unit length distributed continuously over the shaft, $\mu_{a}=$ $R_{a} /(E I)$ is an external (aerial) damping parameter having 
unit $\mathrm{s} / \mathrm{m}^{4}, I_{r}$ is the polar moment of inertia of the shaft about the spinning axis per unit length, $I_{p}=I_{r} L+I_{c}, I_{c}$, is the polar moment of inertia of the part of the coupling and the motor connected to the shaft, $L$ is the length of the shaft, $R_{r}$ is the viscous damping offered to the rotations (due to bearings and the medium), $T_{m}$ is the torque applied on the shaft, $T_{L}$ is the load torque due to dissipative forces acting on the flexural vibrations, i.e., the terms involving the rotor spinning speed in the first two equations of motion and each superscript '.' denotes once total derivative with respect to time. In the left hand side of these equations the first term is due to the elastic forces (strain dependent), the second term is due to the material damping (strain rate dependent) as seen from the fixed frame, and the third term represents moments due to the circulatory forces. The fourth and fifth term represent the inertia force and external damping force respectively. The sixth term introduces the gyroscopic coupling between the orthogonal transverse vibrations. Because the torsional vibrations are neglected, $\dot{\theta}$ does not change along the $z$-axis. Note the sign change in the third terms of the two moment equations that introduce non-potential (and non-conservative) circulatory forces [19].

\subsection{Boundary conditions}

The shaft is supported by ideal bearings, which means that the bending moments and the deflections at the supports are zero. Then the boundary conditions corresponding to the assumed pin-pin supports [16] are specified at $z=0$ and $z=L$ as follows:

$$
\begin{aligned}
& \left.\left(E I \frac{\partial^{2} x}{\partial z^{2}}+\mu_{i} I \frac{\partial}{\partial t}\left(\frac{\partial^{2} x}{\partial z^{2}}\right)+\dot{\theta} \mu_{i} I \frac{\partial^{2} y}{\partial z^{2}}\right)\right|_{z=0, L}=0 \\
& \left.\left(E I \frac{\partial^{2} y}{\partial z^{2}}+\mu_{i} I \frac{\partial}{\partial t}\left(\frac{\partial^{2} y}{\partial z^{2}}\right)-\dot{\theta} \mu_{i} I \frac{\partial^{2} x}{\partial z^{2}}\right)\right|_{z=0, L}=0 \\
& \left.x\right|_{z=0, L}=0 \text { and }\left.y\right|_{z=0, L}=0
\end{aligned}
$$

\subsection{DC motor model}

The torque applied on the shaft $\left(T_{m}\right)$ is transmitted from the DC motor. The brushed DC motor model is, as usual, taken as:

$$
\begin{aligned}
& I_{m}=\frac{U_{s}-U_{b}}{R_{m}}=\frac{U_{s}-\mu_{m} \dot{\theta}}{R_{m}}, \\
& T_{m}=\mu_{m} I_{m}=\left(\frac{\mu_{m}^{2}}{R_{m}}\right)\left(\frac{U_{s}}{\mu_{m}}-\dot{\theta}\right),
\end{aligned}
$$

where $U_{s}$ is the constant electric potential applied across the DC motor's terminals, $\mu_{m}$ is the motor characteristic, $I_{m}$ is the current drawn by the motor, $U_{b}=\mu_{m} \dot{\theta}$ is the back electromotive force developed in the motor's coils, $R_{m}$ is the electrical resistance of the coils and $T_{m}$ is the torque developed by the motor.

\subsection{The Steady-state response of the system}

The steady-state response of flexural vibrations of the rotor system due to unbalance can be found in many standard books on rotor dynamics [20]. During pure synchronous whirl, let us assume a general steady state solution of Eqs. (1) and (2) as:

$$
\begin{aligned}
& y(z, t)=\sum_{i=1}^{\infty} p_{i}(t) X_{i}(z) \\
& x(z, t)=\sum_{i=1}^{\infty} q_{i}(t) X_{i}(z)
\end{aligned}
$$

where $p_{i}(t)$ and $q_{i}(t)$ are generalised coordinates, $i=$ $1,2,3 \ldots$ is the mode number and mode shape is assumed to be $X_{i}(z)=B_{i} \sin \left(\frac{i \pi z}{L}\right)$ so that the boundary conditions are satisfied. Here $B_{i}$ is the amplitude of the ith mode. Substituting Eq.(11) in the first equation of motion Eq. (1) gives

$$
\begin{aligned}
& E I \sum_{i=1}^{\infty} q_{i} X_{i}^{\prime \prime \prime \prime}+\mu_{i} I \sum_{i=1}^{\infty} \dot{q}_{i} X_{i}^{\prime \prime \prime \prime}+\dot{\theta} \mu_{i} I \sum_{i=1}^{\infty} p_{i} X_{i}^{\prime \prime \prime \prime}+ \\
& +\rho a \sum_{i=1}^{\infty} \ddot{q}_{i} X_{i}+\mu_{a} E I \sum_{i=1}^{\infty} \dot{q}_{i} X_{i}-\dot{\theta} I_{P} \sum_{i=1}^{\infty} p_{i} X_{i}^{\prime \prime}- \\
& -I_{d} \sum_{i=1}^{\infty} \ddot{q}_{i} X_{i}^{\prime \prime}=\rho a e \dot{\theta}^{2} \cos (\theta+\varphi)
\end{aligned}
$$

where each prime indicates once partial derivative with respect to $z$.

Let steady state speed of the rotor be $\omega_{r}$ i.e. $\dot{\theta}=\omega_{r}$. Multiplying Eq. (11) by $\mathrm{X}_{\mathrm{i}}$, integrating from 0 to $L$ with respect to $z$ and noting the orthogonality properties, i.e., $\int_{0}^{L} \sin \left(\frac{i \pi z}{L}\right) \sin \left(\frac{j \pi z}{L}\right) d z=0 \forall i \neq j$, yields the steady state unbalance response of the shaft is given as

$$
x(z, t)=\sum_{i=1}^{\infty} \frac{2 e \omega_{r}^{2}(1-\cos (i \pi)) \sin \left(\frac{i \pi z}{L}\right) \cos \left(\omega_{r} t+\phi_{i}\right)}{i \pi p_{i}^{2} \sqrt{\left(1-\frac{\omega_{r}^{2}}{p_{i}^{2}}\left(1-\rho a\left(\frac{i \pi}{L}\right)^{2}\left(I_{r}-I_{d}\right)\right)\right)^{2}+\left(\frac{\mu_{a} E I \omega_{r}}{\rho a p_{i}^{2}}\right)^{2}}},
$$

and modal frequency of $i$-th mode is given by $p_{i}=\left(\frac{i \pi}{L}\right)^{2} \sqrt{\frac{E I}{\rho a}}$.

Similarly,

$$
y(z, t)=\sum_{i=1}^{\infty} B_{i} \sin \left(\frac{i \pi z}{L}\right) \sin \left(\omega_{r} t+\phi_{i}\right),
$$

where

$$
B_{i}=\frac{2 e \omega_{r}^{2}(1-\cos (i \pi))}{i \pi p_{i}^{2} \sqrt{\left(1-\frac{\omega_{r}^{2}}{p_{i}^{2}}\left(1-\rho a\left(\frac{i \pi}{L}\right)^{2}\left(I_{r}-I_{d}\right)\right)\right)^{2}+\left(\frac{\mu_{a} E I \omega_{r}}{\rho a p_{i}^{2}}\right)^{2}}} .
$$

The above two equations yield the deflection of shaft due to the unbalanced harmonic force caused by the constant eccentricity $(e)$ of the shaft in $x$ and $y$ directions, respectively.

\subsection{Instantaneous power balance method}

The mechanical power drawn from the motor during steady-state synchronous whirl is given by 


$$
W_{m}=T_{m} \omega_{r}=\left(\frac{U_{s} \mu_{m}}{R_{m}}-\frac{\mu_{m}^{2}}{R_{m}} \omega_{r}\right) \omega_{r}
$$

and the mechanical power dissipated from the system through the dissipative forces in transverse vibration as well as the dissipation due to shaft rotations is given as

$$
\begin{aligned}
& W_{d}=R_{r} \dot{\theta}^{2}+\int_{0}^{L} \mu_{a} E I\left(\left(\frac{\partial x}{\partial t}\right)^{2}+\left(\frac{\partial y}{\partial t}\right)^{2}\right) d z \\
& \int_{0}^{L} \mu_{i} I\left(\left(\frac{\partial^{4}}{\partial z^{4}}\left(\frac{\partial x}{\partial t}\right)\right) \frac{\partial x}{\partial t}+\left(\frac{\partial^{4}}{\partial z^{4}}\left(\frac{\partial y}{\partial t}\right)\right) \frac{\partial y}{\partial t}\right) d z
\end{aligned}
$$

In steady state whirl, the supplied mechanical power is equal to the dissipated power, i.e., $W_{m}=W_{d}[21,22]$.

Considering only the first three or four modes of vibration (i.e., first mode and third mode, because the odd mode amplitudes are zero) and equating the supplied mechanical power to the dissipated power (i.e., $W_{m}$ $=W_{d}$ ) leads to a ninth order polynomial in $\omega_{r}$ as follows

$$
\begin{aligned}
& a_{9} \omega_{r}^{9}+a_{8} \omega_{r}^{8}+a_{7} \omega_{r}^{7}+a_{6} \omega_{r}^{6}+a_{5} \omega_{r}^{5}+a_{4} \omega_{r}^{4}+ \\
& +a_{3} \omega_{r}^{3}+a_{2} \omega_{r}^{2}+a_{1} \omega_{r}+a_{0}=0
\end{aligned}
$$

If only the first mode vibration is considered and all higher modes are neglected, then one obtains a fifth order polynomial in $\omega_{r}$ from Eq. (15) as follows:

$$
\begin{aligned}
& \left(\mu_{m}^{2}+R_{m} R_{r}+\alpha_{1}\right) \omega_{r}^{5}-U_{s} \mu_{m}(1+C)^{2} \omega_{r}^{4}+\left[D-2 p_{1}^{2}(1+C)\right] . \\
& \cdot\left(\mu_{m}^{2}+R_{m} R_{r}\right) \omega_{r}^{3}-U_{s} \mu_{m}\left[D-2 p_{1}^{2}(1+C)\right] \omega_{r}^{2} \\
& +p_{1}^{4}\left(\mu_{m}^{2}+R_{m} R_{r}\right) \omega_{r}-p_{1}^{4} U_{s} \mu_{m}=0
\end{aligned}
$$

When the rotor speed is sufficiently larger than the first critical speed and nearer to the third critical speed, then the amplitude of first mode vibrations may be neglected in comparison with the third mode vibration amplitudes. In this case, most of the energy supplied by the motor goes towards sustaining the third mode flexural vibrations. If only the third mode vibration is considered and all other modes are neglected then one again obtains a fifth order polynomial in $\omega_{r}$ from Eq. (16) as follows

$$
\begin{aligned}
& \left(\mu_{m}^{2}+R_{m} R_{r}+\alpha_{2}\right) \omega_{r}^{5}-U_{s} \mu_{m}(1+9 C)^{2} \omega_{r}^{4} \\
& +\left[D-2 p_{3}^{2}(1+9 C)\right] \times\left(\mu_{m}^{2}+R_{m} R_{r}\right) \omega_{r}^{3}- \\
& U_{s} \mu_{m}\left[D-2 p_{3}^{2}(1+9 C)\right] \omega_{r}^{2}+p_{3}^{4}\left(\mu_{m}^{2}+R_{m} R_{r}\right) \omega_{r} \\
& -p_{3}^{4} U_{s} \mu_{m}=0
\end{aligned}
$$

\subsection{Stability criteria of the Steady State Forced Response}

Positive real roots of Eq. (16), i.e., admissible solutions, yield the equilibrium states of the system under consideration. Some of these equilibriums are stable, whereas the others are unstable (saddles). Based on the approach followed in $[12,16,19]$, one may conclude that a stable constant energy state exists under the following condition:

$$
\left.\frac{d}{d \omega_{r}}\left(W_{m}-W_{d}\right)\right|_{\omega_{r}=\sigma_{r}}<0,
$$

where $\omega_{r}$ is an admissible (real positive) solution obtained from Eq.(15). Use of Eqs. (13) and (14) in inequality (18) yields

$$
\left.\frac{d}{d \omega_{r}} \int_{\int_{0}^{L}}^{L}\left[\begin{array}{l}
\left(\frac{U_{s} \mu_{m}}{R_{m}}-\frac{\mu_{m}^{2}}{R_{m}} \omega_{r}\right) \omega_{r}-R_{r} \omega_{r}^{2}- \\
\mu_{a} E I\left(\left(\frac{\partial x}{\partial t}\right)^{2}+\left(\frac{\partial y}{\partial t}\right)^{2}\right)+ \\
\left.\left.\mu_{i} I\left(\left(\frac{\partial^{4}}{\partial z^{4}} \frac{\partial x}{\partial t}\right) \frac{\partial x}{\partial t}+\left(\frac{\partial^{4}}{\partial z^{4}} \frac{\partial y}{\partial t}\right) \frac{\partial y}{\partial t}\right)\right)\right] d z
\end{array}\right)\right|_{\omega_{r}=\sigma_{r}}<0,
$$

where all real positive roots of Eq. (15) are allowable solutions $\omega_{r}=\varpi_{r}$ and $y$ and $x$ are given by Eq. (9) and Eq. (10), respectively, with $\omega_{r}=\varpi_{r}$.

\section{RESULT AND DISCUSSION}

The following representative values are considered for numerical studies:

$$
\begin{aligned}
& L=2 \mathrm{~m}, \quad \mu_{a}=10^{-14} \mathrm{Kg}, E=1.2 \times 10 \mathrm{~N} / \mathrm{m}, e=10^{-3} \mathrm{~m}, \\
& \rho=7800 \mathrm{~kg} / \mathrm{m}^{3}, \mu_{i}=10^{-6} \times E, a=9.81 \times 10^{-5} \mathrm{~m}^{2}, \\
& I=1.994 \times 10^{-9} \mathrm{~m}^{4}, \\
& \mu_{m}=0.34 \mathrm{Nm} / \mathrm{A}, R_{m}=600 \Omega, \\
& R_{r}=10^{-5} \mathrm{~N} . \mathrm{m} . \mathrm{s} / \mathrm{rad} \text { and } I_{p}=2 I_{d}=2 \rho I .
\end{aligned}
$$

For the chosen parameters, the model frequencies are calculated from:

$$
\begin{aligned}
& p_{i}=\left(\frac{i \pi}{L}\right)^{2} \sqrt{\frac{E I}{\rho a}}, i=1,2,3 \ldots \text { are } p_{1}=100.1463 \mathrm{rad} / \mathrm{sec}, \\
& p_{2}=400.585 \mathrm{rad} / \mathrm{sec}, p_{3}=901.316 \mathrm{rad} / \mathrm{sec}, \text { etc } .
\end{aligned}
$$

The steady state characteristic is defined by the nondimensional quantities: the non dimensional rotor speed $\omega_{r}^{*}=\omega_{r} / p_{1}$ and the non-dimensional whirl amplitude $\beta=B p_{1}^{2} /\left(\pi^{2} g\right)$, where $g$ is the acceleration due to gravity, $B=\sum_{i=1}^{m} B_{i}$ is the maximum flexural amplitude that can be reached during steady state and $m$ is the number of modes considered in the analysis.

The Sommerfeld effect occurs around the third natural frequency $\left(\omega_{r}^{*}=9\right)$, which is $901.316 \mathrm{rad} / \mathrm{sec}$.

The non-dimensional rotor spin speed $\omega_{r}^{*}=\omega_{r} / p_{1}$ (positive real roots of Eq. (16)) and amplitude are plotted against the supply voltage in Figs. 2 and 3, respectively, for the zone, where the first mode Sommerfeld effect is observed. In the coast-up operation (i.e., while voltage is gradually increased), the rotor spin speed is entrained at values near the natural frequency $\omega_{r}^{*}=$ $\omega_{r} / p_{1}$ for a small range of voltage (points ' $\mathrm{a}$ ' to ' $\mathrm{b}$ ') and maximum flexural vibration amplitude is observed.

As the supply voltage is gradually increased further, the rotor spin speed suddenly jumps to a much higher value (point 'b' to a point 'd' not shown in Fig. 3) and the flexural vibration amplitude drops to a much lower value. 


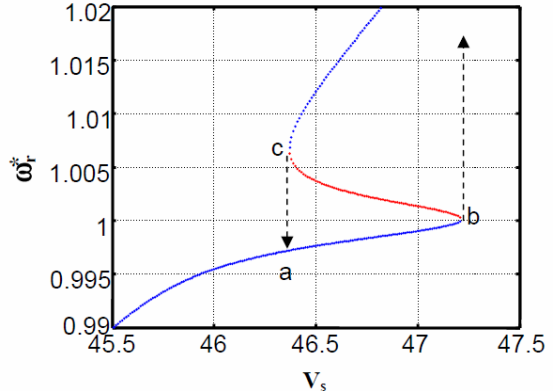

Figure 2. Steady-state shaft speed for supply voltage values in the range of first mode Sommerfeld effect obtained from three mode approximation

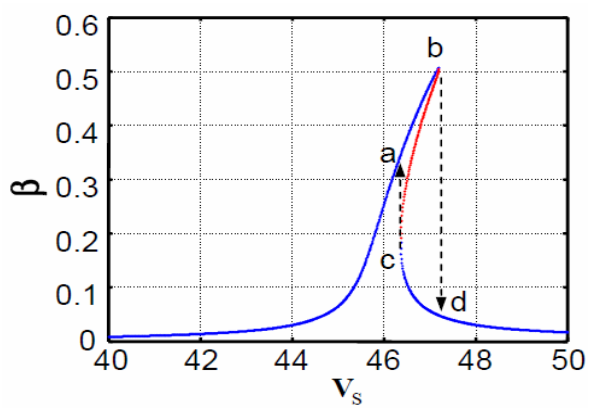

Figure 3. Maximum possible steady-state amplitude for supply voltage values in therange of first mode Sommerfeld effect obtained from three mode approximation.

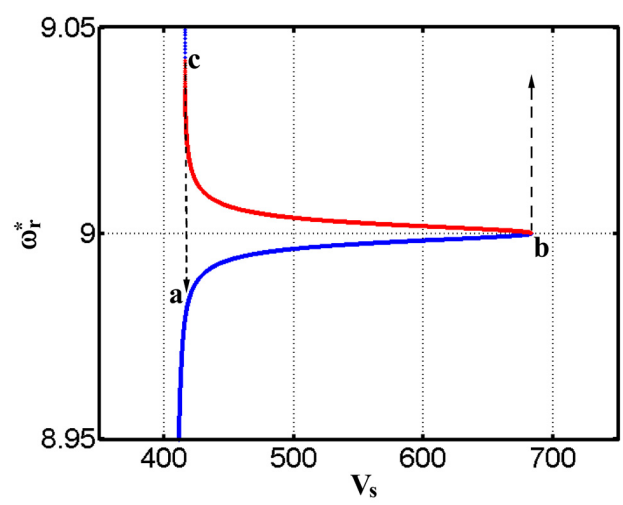

Figure 4. Steady-state shaft speed for supply voltage values in the range of third mode Sommerfeld effect obtained from three mode approximation

\subsection{Transient Response during Passage Through Resonance}

The normalized variables used to plot the transient responses are chosen to be compatible with the steadystate results. These normalized variables are rotor spin speed $(\varpi)=\dot{\theta} / p_{1}$ and the normalized whirl amplitude $\gamma=\left(\sqrt{x^{2}+y^{2}}\right) p_{1}^{2} / \pi^{2} g$, where $\dot{\theta}$ transient shaft speed and $x$ and $y$ are the contemporary position of the shaft centerline at a given node, where 17 nodes model of the sahft is considered. The steady-state results do not depend upon the rotary inertia $\left(I_{c}\right)$ of the coupling and the rotor of the motor. However, transient response is dependent on that parameter. In the simulations, a value $I_{c}=0.02$ $\mathrm{kg}-\mathrm{m}^{2}$ has been chosen. If the value of $I_{c}$ is high, then it takes a lot of time for the shaft to accelerate towards its steady-state speed, and consequently the simulation time requirement becomes too large. On the other hand, if the value of $I_{c}$ is low, then the shaft accelerates too fast and can pass through the resonance quite easily; thus hiding the Sommerfeld effect zone.

The transient responses for rotor spin speed and flexural vibration amplitudes, shown in Figs. 5 and 6 respectively, show the convergence of the responses ( and $\gamma_{9}$ ) to the respective steady-state values.

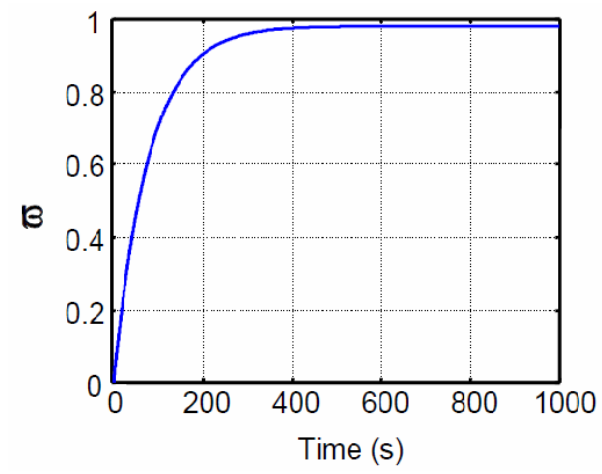

Figure 5. Transient response showing time evolution of normalized shaft speed for Us $=\mathbf{4 5 . 1}$ Volt.

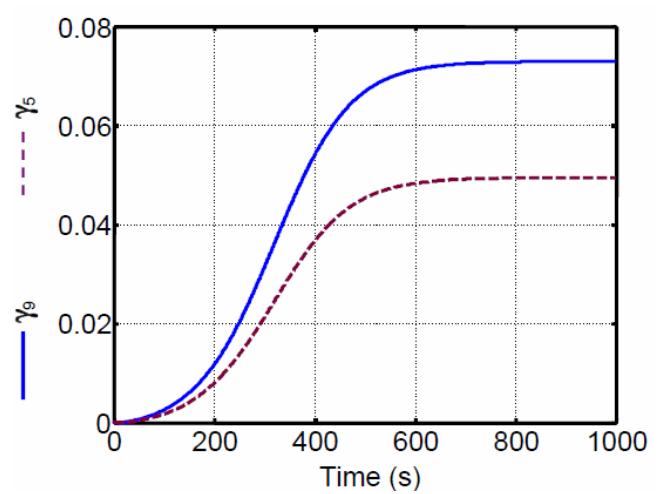

Figure 6. Transient response showing time evolution of normalized maximum amplitudes at 5th and 9th nodes of a 17 node model for Us $=45.1$ Volt.

\section{CONCLUSION AND FUTURE WORK}

Dynamics of an internally and externally damped eccentric flexible spinning shaft driven through a nonideal source (a DC motor) is studied in this paper. The motivation of this research is the first step to study the dynamic response of a complex rotor system driven by DC motor. DC motor is one of the non-ideal energy sources, whch causes generation of the Sommerfeld effect in the rotor system characterized by the jump phenomena $[9,12,19,22]$. This helps to determine the stability criteria of the high speed rotor shaft, when the system passes through the various resonance frequencies. The steady-state results predicted by the power balance method are further validated through numerical simulations. The transient responses of the normalized amplitude and speed are also shown. Numerical results are in good agreement with the work reported in [9].

Based on this work, one may work on a discrete multi-disk rotor system that would show the Sommerfeld effect, when the motor speed passes through the various resonance frequencies of the rotor system. Drive 
structure interaction for other kinds of non-ideal sources such as electrical induction motor, synchronous motors and hydraulic motors may be studied.

\section{REFERENCES}

[1] Sommerfeld, A., Beiträge Zum Dynamischen Ausbau Der Festigkeitslehe, Physikal Zeitschr, 1902, 3, 266-286.

[2] Timoshenko, S., Vibration Problems in Engineering, 1961 (Van Nostrand, Princeton, NJ).

[3] Kononenko, V.O., Vibrating Systems with Limited Excitation [in Russian], 1964 (Nauka, Moscow).

[4] Blekhman, I.I., Vibrational Mechanics: Nonlinear Dynamic Effects, General Approach, Applications, 2000 (World Scientific, Singapore).

[5] Nayfeh, A., and Mook, D., Nonlinear Oscillations, 1979 (Wiley-Interscience, NY).

[6] Alifov, A.A., and Frolov, K.V., Interaction of Nonlinear Oscillatory Systems with Energy Sources, 1990 (Taylor \& Francis, London).

[7] M. Eckert, The Sommerfeld effect: theory and history of a remarkable resonance phenomenon, Eur. J. Phys. 17 (5) (1996) 285-289.

[8] J.L.P. Felix, J.M. Balthazar,: Comments on a nonlinear and nonideal electro-mechanical damping vibration absorber, Sommerfeld effect and energy transfer, Nonlinear Dyn. 55 (1-2) (2009) 1-11.

[9] Samantaray A.K., Dasgupta S.S., Bhattacharyya R.,: Sommerfeld effect in rotationally symmetric planar dynamical systems, Int. J. Eng. Sci. 48 (1) (2010) 21-36.

[10] J.M. Balthazar, D.T. Mook, R.M.L.R.F. Brasil, A. Fenili, D. Belato, J.L.P. Felix, H.I. Weber,: Recent results on vibrating problems with limited power supply, Meccanica 330 (7) (2002) 1-9.

[11] M.F. Dimentberg, L. McGovern, R.L. Norton, J. Chapdelaine, R. Harrison,: Dynamics of an unbalanced shaft interacting with a limited power supply, Nonlinear Dyn. 13 (1997) 171-187.

[12] Dasgupta S.S., Samantaray A.K., Bhattacharyya R.,: Stability of an internally damped non-ideal flexible spinning shaft, International Journal of Non-linear Mechanics, 2010, 45(3), 286-293.

[13] Piccirillo V., Tusset A.M. and Balthazar J.M.,: Dynamical Jump Attenuation in a Non-ideal System Through a Magnetorheological Damper, Journal of Theoretical and Applied Mechanics, 52, 3, pp. 595-604, Warsaw 2014.

[14] Balthazar J.M.,: Nonlinear Dynamic Interactions and Phenomena:Vibrating Systems with Limited Power Supply: An Emergent Topic after Prof. Kononenko, Proceedings of the 5th International
Conference on Nonlinear Dynamics, September 2730, 2016, Kharkov, Ukraine.

[15] Walter V. Wedig,: Jump phenomena in roadvehicle dynamics, International Journal of Dynamics and Control, June 2016, Volume 4, Issue 2, pp 213-220.

[16] Samantaray, A.K., Dasgupta, S.S., and Bhattacharyya, R.,: Bond graph modeling of an internally damped non-ideal flexible spinning shaft, Journal of Dynamical Sytems, Measurement, and Control, Trans. ASME, 2010, 132(6), 061502-9.

[17]L. Meirovitch,:Analytical Methods in Vibrations, Macmillan, New York, 1967.

[18]D. ter Haar,: Elements of Hamiltonian Mechanics, Pergamon Press, Oxford, 1964.

[19] Samantaray, A. K. et al.:, "Some Studies on Rotors With Polynomial Type Nonlinear External and Internal Damping," Int. J. Non-Linear Mech. 2006, 41, pp. 1007-1015.

[20] Genta, G., Dynamics of Rotating Systems, 2005 (Springer).

[21] Montagnier, O., and Hochard, Ch.,: Dynamic instability of supercritical drive shafts mounted on dissipative supports-Effects of viscous and hysteretic internal damping, J. Sound and Vib., 2007, 305(3), 378-400.

[22] Samantaray, A.K., Bhattacharyya, R., and Mukherjee, A.,: On the stability of Crandall gyropendulum, Physics Letters A, 2008, 372, 238-243.

\section{СТАЦИОНАРАН И ТРАНЗИЈЕНТАН ОДЗИВ ФЛЕКСИБИЛНОГ ЕКСЦЕНТРИЧНОГ РОТАЦИОНОГ ВРАТИЛА}

\section{С.С. Дасгупта, J.А. Рајан}

Истражена је стационарна и транзијентна динамика флексибилног ротационог вратила са ексцентричношћу кога покреће мотор једносмерне струје (тј. неидеални извор енергије) са унутрашњим и спољашњим пригушењем. Утврђено је да структурни одзив вибрационог система за који је везан неиделни извор може да се понаша као енергетски понор у одређеним условима, тако да се део енергије добијен од извора утроши на вибрирање структуре, а не на повећање брзине погона. Феномен је познат као Зомерфилдов ефекат. Зомерфилдов ефекат који се одликује феноменом скока проучен је помоћу стационарне амплитуде добијене методом тренутног уравнотежења снаге и потврђен је нумеричком симулацијом. Такође су приказани транзијентни одзиви бездимензионе амплитуде и брзине вратила повећаване у времену кроз резонанцију првог мода. 